\title{
Pengaruh Kedisiplinan Terhadap Prestasi Kerja Karyawan Pada PT. Handaru Nusantara Gemilang (Dapoer Intan)
}

\author{
Sareno \\ Dosen Fakultas Teknik Universitas Pamulang \\ Email : dosen01650@unpam.ac.id
}

\begin{abstract}
ABSTRAK
Penelitian ini bertujuan untuk mengaji dan menganalisis Pengaruh Kedisiplinan terhadap Prestasi Kerja Karyawan pada PT. Handaru Nusantara Gemilang (Dapoer Intan). Berdasarkan hasil penelitian Kedisiplinan pada PT. Handaru Nusantara mengalami penurunan disebabkan karena tingginya angka absensi karyawan sehingga berdampak pada penurunan Prestasi Kerja Karyawan.

Metode penelitian yang digunakan adalah Deskriptif Kuantitatif sedangkan teknik pengumpulan data dengan teknik Kuesioner dan Observasi Teknik kuiesioner dilakukan dengan menyebar angket kepada 60 karyawan untuk mengumpulkan data dengan meminta setiap karyawan menjawab setiap permyataan yang tertera pada angket, dan observasi dengan melakukan pengamatan langsung kepada karvawan vang sedang bekerja

Berdasarkan analisis yang penulis lakukan mendapatkan hasil dari Variabel $\mathrm{X}$ yaitu Kedisiplinan cukup baik berdasarkan hasil olahan Kuesioner yang disebarkan dapat dilihat dari jawaban responden yang menjawab SS - 54 \% . S - 41 $\%$. R : $4 \%$. TS - 1\%. STS 0 \% dan adapun Variabel Y yaitu Prestasi Kerja Karyawan pada PT. Handaru Nusantara Gemilang cukup baik, dapat dilihat dari jawaban responden yang menjawab ss - $48 \%, \mathrm{~S}-46 \%$, R - $4 \%$, TS $1 \%$ STS 1 $\%$. Jadi, terdapat hubungan yang kuat antara Kedisiplinan terhadap Prestasi Kerja Karyawan dengan melalui perhitungan analisis Korelasi Product Moment, maka diketahui bahwa nilai korelasi sebesar 0,66063 dengan demikian terdapat hubungan positif yang kuat antara variabel (X) dengan variabel (Y) Untuk mengetahui besarnya sumbangsih (kontribusi) variabel $(\mathrm{X})$ yang berpengaruh dengan variabel (Y) menggunakan Koefisen Determinasi (KD) yang diperoleh 43,64 \% dan sisanya ( $100 \%-43,64 \%$ ) sebesar 56,36\% dipengaruhi faktor lain yang tidak diteliti oleh penulis. Berdasarkan hasil uji, diperoleh 6,7020 sedangkan dari tebel 2,002, berarti thitung rabet yang artinya bahwa Ho ditolak dan $\mathrm{H}$ diterima, maka ada pengaruh yang signifikan antara Kedisiplinan terhadap Prestasi Kerja Karyawan pada PT. Handaru Nusantara Gemilang
\end{abstract}

\section{Kata Kunci : Kedisiplinan dan Prestasi Kerja}




\section{PENDAHULUAN}

\section{Latar Belakang}

Sumber daya mempunyai peranan baik secara perorangan maupun kelompok, dan sumber daya manusia merupakan salah satu penggerak utama atas kelancaran jalannya kegiatan sebuah organisasi, bahkan maju mundurnya perusahaan ditentukan oleh keberadaan sumber daya manusianya. Untuk itu sebuah perusahaan perlu memperhatikan dan mengatur keberadaan karyawannya sebagai usaha meningkatkan usaha yang baik

Manusia sebagai tenaga kerja mempunyai peranan penting didalam era globalisasi saat ini. Walaupun ilmu pengetahuan dan teknologi berkembang dengan pesat dan serba canggih namun peranan tenaga kerja tidak dapat di abaikan begitu saja. Sumber daya manusia harus ditingkatkan, salah satu caranya adalah dengan memberikan motivasi kerja agar tidak ada salah paham antar karyawan dalam produktivitas kerja lebih lagi. Tanpa memotivasi tenaga kerja maka untuk memperoleh hasil yang optimal akan sulit. Guna mencapai tingkat kualitas yang tinggi, maka perusahaan harus mengetahui dan melayani kebutuhan tenaga kerja. Begitupun dengan pimpinannya harus memberikan pengawasan yang optimal untuk karyawan.

Salah satu hal yang mempengaruhi prestasi kerja karyawan adalah disiplin. Disiplin sendiri merupakan satu dari beberapa faktor yang mempunyai prestasi karyawan. Karena tanpa adanya disiplin, maka segala kegiatan yang akan dilakukan akan mendatangkan hasil yang kurang memuaskan atau tidak sesuai dengan harapan. Hal ini dapat melibatkan kurangnya pencapaian sasaran dan tujuan organisasi atau perusahaan serta dapat juga menghambat jalannya program organisasi yang dibuat.

Dibutuhkan peningkatan prestasi kerja karyawan agar dapat melaksanakan tugas yang ada sebaik mungkin. Karena itu, faktor disiplin kerja mempunyai pengaruh serta peran yang penting terhadap peningkatan prestasi kerja karyawan. Jika dilihat secara ril, faktor kedisiplinan memegang peranan yang amat penting dalam pelaksanaan tugas sehari-hari para pegawai. Demikian juga karyawan yang mempunyai kedisiplinan akan menaati peraturan yang ada dalam lingkungan kerja dengan kesadaran yang tinggi tanpa ada rasa paksaan pada akhimya karyawan yang mempunyai kedisiplinan kerja yang tinggi akan mempunyai kinerja yang baik bila dibanding dengan para karyawan yang bermalas-malasan karena waktu kerja dimanfaatkannya sebaik mungkin untuk melaksanakan pekerjaan sesuai dengan target yang diterapkan.

Prestasi kerja karyawan merupakan salah satu faktor yang perlu diperhatikan dan ditangani secara serius oleh perusahaan, karena karyawan merupakan sumber daya yang menggerakan dan mengarabkan organisasi. kinerja yang dihasilkan akan semakin baik jika perusahaan memandang setiap karyawan adalah aset yang bernilai tinggi untuk mencapai tujuan.

\section{PEMBATASAN MASALAH}

Mengingat luasnya cakupan penelitian ini dan sekaligus untuk menghindari terjadinya penafsiran yang berbeda-beda maka penulis 
hanya membatasi secara spesifik. Adapun pembatasan masalah sebagai berikut:

1. Kedisiplinan adalah sikap kesediaan dan kerelaan seseorang untuk mematuhi dan menaati norma-norma peraturan yang berlaku disekitarnya.

2. Prestasi kerja adalah sebagai hasil kerja yang telah dicapai seseorang dari tingkah laku kerjanya dalam melaksanakan aktivitas kerja.

3. Mengingat terbatasnya waktu, tenaga, dan biaya penelitian hanya tentang pengaruh disiplin kerja terhadap prestasi kerja karyawan pada PT. Handaru Nusantara Gemilang.

4. Penelitian ini dilakukan pada PT. Handaru Nusantara Gemilang sejak tahun 2016-2017.

\section{TUJUAN DAN MANFAAT PENULISAN}

\section{Tujuan Penelitian}

a. Untuk mengetahui tingkat kedisiplinan karyawan pada PT. Handaru Nusantara Gemilang

b. Untuk mengetahui tingkat prestasi kerja karyawan pada PT Handaru Nusantara Gemilang.

c. Untuk mengetahui pengaruh kedisiplinan terhadap prestasi kerja karyawan pada PT. Handaru Nusantara Gemilang

\section{Manfaat Penulisan}

Selain tujuan diatas. penulis mengharapkan adanya kegunaan dari penelitian yang dilakukan adalah sebagai berikut :

a. Manfaat Teoritis
1). Bagi penulis melakukan
Dengan penelitian,

pengetahuan dan wawasan pencliti akan bertambah. Peneliti lebih memahami praktek tentang kepemimpinan, motivasi, disiplin kerja dan konsep kinerja karyawan yang berhubungan dengan prestasi kerja karyawan pada PT. Handaru Nusantara Gemilang.

2). Bagi pihak Unpam

Memberikan kontribusi ilmu pengetahuan dan menambah wawasan dalam bidang manajemen bagi pembaca khususnya tentang kedisiplinan dan prestasi kerja karyawan.

b. Manfaat Praktisi

1) Memberikan informasi yang bermanfaat bagi perusahaan dalam rangka pengembangan dan pelaksanaan kedisiplinan demi tercapainya tujuan perusahaan.

2) Hasil penelitian dapat dijadikan sebagai bahan perlindungan dalam upaya perbaikan kepemimpinan, motivasi dan disiplin kerja sehingga akan tercapai prestasi kerja karyawan sesuai dengan yang diharapkan oleh PT. Handaru Nusantara Gemilang.

\section{KERANGKA BERPIKIR}

Indikator-indikator kedisiplinan menurut Veithzal Rivai (dalam Kasmir, 2016:355), adalah sebagai berikut:

1. Kehadiran

Hal ini menjadi indikator yang mendasar untuk mungukur kedisiplinan, dan biasanya pegawai yang memiliki disiplin kerja rendah 
terbiasa untuk terlambat dalam bekerja.

2. Ketaatan pada peraturan kerja. Pegawai yang taat pada peraturan kerja tidak akan melalaikan prosedur kerja dan akan selalu mengikuti pedoman kerja yang ditetapkan oleh perusahaan.

3. Ketaatan pada standar kerja.

Hal ini dapat dilihat melalui besamya tanggung jawab pegawai terhadap tugas yang diamanahkan kepadanya.

4. Tingkat kewaspadaan tinggi Pegawai memiliki kewaspadaan tinggi okan selalu berhati-hati, penuh perhitungan dan ketelitian dalam bekerja, serta sclalu menggunakan sesuatu secara efektif dan efisien.

5. Bekerja etis

Berapa pegawai mungkin melakukan tindakan yang tidak sopan ke pelanggan atau terlibat dalam tindakan yang tidak pantas.

\section{Pengaruh Kedisiplinan terhadap Prestasi Kerja Karyawan pada PT. Handaru Nusantara Gemilang}

\begin{tabular}{|c|c|}
\hline $\begin{array}{c}\text { Kedisiplinan } \\
\text { Variabel X }\end{array}$ & $\begin{array}{c}\text { Prestasi Kerja } \\
\text { Variabel } \\
\text { Y } \\
\end{array}$ \\
\hline $\begin{aligned} & \text { Indikator : } \\
& \text { 1. } \text { Kehadiran } \\
& \text { 2. } \text { Ketaatan } \\
& \text { pada } \\
& \text { peraturan } \\
& \text { kerja } \\
& \text { 3. } \text { Ketaatan } \\
& \text { pada standar } \\
& \text { kerja } \\
& \text { 4. } \text { Tingkat } \\
& \text { kewaspadaa } \\
& \text { n tinggi } \\
& \text { 5. } \text { Bekerja etis }\end{aligned}$ & $\begin{aligned} & \text { Indikator: } \\
& \text { 1. } \text { Kualitas } \\
& \text { (Mutu) } \\
& \text { 2. } \text { Kuantitas } \\
& \text { (Jumlah) } \\
& \text { 3. } \text { Penekanan } \\
& \text { Biaya } \\
& \text { 4. } \text { Penguasaa } \\
& \mathrm{n} \\
& \text { 5. } \text { Hubungan } \\
& \text { antara } \\
& \text { Karyawan }\end{aligned}$ \\
\hline
\end{tabular}

Sumber : Veithzal Rivai dalam Kasmir (2016:355) ; Sinambela (2016:415)

\section{HIPOTESIS PENELITIAN}

Menurut Sugiono (2009:96), hipotesis merupakan jawaban sementara terhadap rumusan masalah penelitian, dimana rumusan masalah penclitian dinyatakan dalam bentuk pertanyaan. Tujuannya untuk mencari jawaban sementara dan sebagai pengarah dalam pencarian data sehingga dalam pembahasan masalah tidak menyimpang jauh dari tujuan peneliti yang telah ditetapkan. Hipotesis pada umumnya suatu anggapan yang mungkin benar dan sering kali digunakan sebagai dasar dalan pengambilan keputusan, pemecahan persoalan, atau untuk dasar pembuatan keputusan. Dalam pembuatan keputusan, hipotesis harus diuji terlebih dahulu dengar menggunakan data hasil observasi yang dikumpulkan berdasarkan kenyataan yang ada.

Berdasarkan latar belakang masalah dan kerangka pemikiran yang ada, maka hipotesis dalam penulisan skripsi ini dapat dirumuskan sebagat berikut:

$\mathrm{H} 0: \beta=0$ tidak terdapat pengaruh kedisiplinan terhadap prestasi kerja karyawan PT. Handaru Nusantara Gemilang

$\mathrm{H1}: ß \# 0$ terdapat pengaruh kedisiplinan terhadap prestasi kerja karhean PT . Handaru Nusantara Gemilang.

\section{TINJAUAN TEORI}

\section{A. Manajemen Sumber Daya \\ Manusia}

\section{Pengertian Manajemen}

Pengertian manajemen secara umum dapat diartikan sebagau rangkaian proses untuk mencapai tujuan suatu organisasi dengan cara bekerja sama dengan sumber daya 
yang dimiliki organisasi. Secara lebih sifik definisi manajemen ialah ilmu dan seni perencanaan pengorganisasian, pengarahan dan pengawasan terhadap usaha-usha para anggota organisasi dan penggunaan sumber daya organisasi untuk mencapai tujuan yang telah ditetapkan sebelumnya.

Beberapa pengertian manajemen menurut para ahli :

a. Malayu S.P. Hasibuan (2017:10) mengutarakan, pengertian manajemen adalah "ilmu dan seni mengatur hubungan-hubungan peranan tenaga kerja agar efektif dan cfisien membantu terwujudnya tujuan perusahaan, karyawan dan masyarakat."

b. George R Terry yang dikutip oleh Rivai (2012:10) memberikan definisi; "Manajemen adalah suatu proses yang membedakan atas perencanaan, pengorganisasian, penggerakan pelaksanaan, dan pengawasan dengan memanfaatkan baik ilmu maupun seni agar dapat menyelesaikan tujuan yang telah ditetapkan sebelumnya".

Berdasarkan penjelasan diatas, penulis dapat menyimpulkan bahwa manajemen adalah proses mengordinasikan aktifitas-aktifitas kerja sehingsa dapat selesai secara efektif dan cfisien dengan dan melalui orang lain untuk mencapai tujuan yang telah ditetapkan oleh organisasi

\section{Fungsi Utama dalam Manajemen (POACH)}

Didalam perusahaan, untuk memperoleh hasil manajemen secara maksimal, para manajer didalam perusahaan haruslah mampu menguasai seluruh fungsi manajemen yang ada. Menurut G.R. Terry, 4 fungsi utama manajemen, yaitu

a. Fungsi Perencanaan (Planning)

Planning merupakan suatu aktivitas menyusun, tujuan perusahaan lalu dilanjutkan dengan menyusun berbagai rencana-rencana guna mencapai tujuan perusahaan yang sudah ditentukan. Planning dilaksanakan dalam penentuan tujuan organisasi secara keseluruhan dan merupakan langkah yang terbaik untuk mencapai tujuannya itu Pihak manajer mengevaluasi berbagai rencana altematif sebelum pengambilan dan tindakan kemudian menelagh rencana yang terpilih apakah sesuai bisa dipergunakan untuk mencapai tujuan. Perencanaan adalah proses awal yang paling penting dari seluruh tungsi manajemen, karena fungsi yang lain tak akan bisa berjalan tanpa planning. Ada beberapa aktivitas dalam fungsi perencanaan:

1) Pembagian perencanaan

2) Menetapkan arah tujuan serta target bisnis

3) Menentukan sumber daya yang dibutuhkan

4) Menyusun strategi dalam pencapaian tujuan dan target tersebut

5) Menetapkan standar kesuksesan dalam pencapaian suatu tujuan dan target bisnis.

Perencanaan (planning) dari sudut pandang jenjang manajemen bisa dibagi beberapa jenjang:

1) Perencanaan Jenjang Atas (Top Level Planning), perencanaan dalam jenjang ini bersifat strategis. Memberikan petunjuk umum, rumusan tujuan, pengambilan keputusan serta memberikan pentunjuk pola penyelesaian dan 
sifatnya menyeluruh. Top level planning ini penekanannya pada tujuan jangka panjang organisasi dan tentu saja menjadi tangungjawab manajemen puncak.

2) Perencanaan Jenjang Menengah (Middle Level Planning), dalam jenjang perencanaan ini sifatnya lebih administratif meliputi berbagai cara menempuh tujuan dari sebuah perencanaan dijalankan

3) Perencanaan Jenjang Bawah (Low Level Planning) perencanaan in memfokuskan diri dalam menghasilkan sehingga planning ini mengarah kepada aktivitas operasional dan perencanaan ini menjadi tanggung jawab manajemen pelaksana

b. Fungsi Pengorganisasian (Organizing) Organizing adalah suatu aktivitas pengaturan dalam sumber daya manusia dan sumber daya fisik yang lainnya yang dimiliki oleh perusahaan untuk bisa melaksanakan rencana yang sudah ditetapkan dan mencapai tujuan utama perusahaan, Organizing dapat membuat manajer mudah dalam melaksanakan pengawasan serta penentuan personil yang diperlukan untuk menjalankan tugas yang sudah dibagi bagi. Pengorganisasian bisa dijalankan dengan menetukan tugas apa yang harus dikerjakan, siapa personil yang menjalankannya, bagaimana tugasnya dikelompokkan, siapa yang harus bertanggung jawab terhadap tugas tersebut.

Aktivitas yang ada dalam fungsi pengorganisasian (Organizing):

1) Mengalokasikan sumber daya, menyusun dan menetapkan tugastugas serta menetapkan prosedur yang dibutuhkan
2) Menetapkan struktur perusahaan yang menujukan adanya garis kewenangan serta tanggung-jawab

3) Aktivitas perekrutan, menyeleksi orang, pelatihan serta pengembangan tenaga kerja

4) Aktivitas penempatan tenaga kerja dalam posisi yang pas dan paling tepat.

Beberapa manfaat organizing antara lain :

1) Menjalankan tugas

2) Ada pembagian tugas yang jelas

3) Personil dalam perusahaan mengetahui tugas apa yang akan dijalankan untuk mencapai tujuan

4) Pendelegasian wewenang didalam manajemen atas (puncak) kepada manajemen pelaksana

5) Mempunyai manajer puncak yang profesional guna mengkoordinasikan semua aktivitas

\section{c. Fungsi Pengarahan (Directing)}

Directing alias fungsi pengarahan merupakan fungsi untuk meningkatkan efektivitas dan efisiensi kinerja dengan optimal dan menciptakan suasana lingkungan kerja yang dinamis, sehat dan yang lainnya. Ada beberapa aktivitas yang dilakukan pada fungsi pengarahan :

1) Mengimplementasikan suatu proses kepemimpinan, pembimbingan, dan memberikan motivasi kepada pekerja supaya bisa bekerja dengan efektif serta efisien dalam mencapai tujuan yang ditetapkan

2) Memberi tugas serta penjelasan secara rutin tentang pekerjaan

3) Menjelaskan semua kebijakan yang sudah ditetapkan 
d. Fungsi Pengendalian / Pengawasan (Controlling)

Controlling merupakan kegiatan dalam menilai suatu kinerja yang berdasarkan pada standar yang sudah dibuat perubahan atau suatu perbaikan apabila dibutuhkan. Aktivitas dalam fungsi pengendalian ini misalnya:

1) Mengevaluasi keberhasilan dalam proses mencapai tujuan dan target mengikuti indikator yang sudah ditetapkan

2) Menempuh langkah klarifikasi serta koreksi atas terjadinya penyimpangan yang ditemukan 3 ) Memberi alternatif solusi atas masalah yang terjadi dalam mencapai tujuan yang ditetapkan.

Controlling atau fungsi pengawasan bisa berjalan dengan efektif jika - hal-hal ini diperhatikan:

1) Jalur (Routing), manajer harus bisa menetapkan cara atau jalur guna bisa mengetahui letak dimana sesuatu sering terjadi suatu kesalahan

2) Penetapan waktu (Scheduling), dalam penetapan waktu, manajer harus bisa menetapkan dengan tugas kapan semestinya pengawasan itu dijalankan. Terkadang, pengawasan yang dijadwal tidak efisien dalam menemukan suatu kesalahan, dan sebaliknya yang dilakukan secara mendadak terkadang malah lebih berguna.

3) Perintah Pelaksanaan (Dispatching), adalah pengawasan yang berupa suatu perintah pelaksanaan pada pekerjaan yang bertujuan suatu pekerjaan itu bisa selesai tepat waktu. Dengan perintah seperti ini pelaksanaan suatu pekerjaan bisa terhindar dari kondisi yang terkatung-katung. Jadi, pada akhirnya bisa didentifikasikan siapa yang telah berbuat kesalahan

4) Tindak Lanjut (Follow Up) apabila penimpin menenukan kesalahan maka seharusnya pemimpin tersebut mencari solusi atas pemuasalahan itu. Dengan memberi peringatan pada pekerja yang dengan sengaja ataupun tidak sengaja berbuat kesalahan dan memberikan petunjuk supaya kesalahan yang sama tak terulang lagi.

\section{Pengertian Sumber Daya Manusia (SDM)}

Sumber Daya Manusia (SDMI) adalah individu produk yang bekerja sebagai penggerak suatu organisasi, baik itu di dalam institus maupun perusahaan yang memiliki fungsi sebagai aset sehingga hanus dilatih dan dikembangkan kemampuannya. Pengertian sumber daya manusia makro secara umum terdiri dari dua yaitu SDM makro yaitu jumlah penduduk dalam usia produktif yang ada di sebuah wilayah, dan SDM mikro dalam arti sempit yaitu individu yang bekerja pada sebuah institusi atau perusahaan.

\section{Unsur-unsur Manajemen Sumber Daya Manusia}

Manajemen hanya merupakan alat untuk mencapai tujuan yang terwujudnya tujuan diinginkan. Manajemen yang baik akan memudahkan terwujudnya tujuan perusahaan, pegawaí, dan masyarakat. Dengan manajemen daya guna dan hasil guna unsur-unsur manajemen akan dapat ditingkatkan 
Adapun unsur-unsur manajemen itu terdini dani beberapa elemen yang disingkat dengan $6 \mathrm{M}$ menurut Malayu S. P Hasibuan (2017:9) antara lain:

a. Man

Man merupakan keseluruhan sumber daya manu ia yang ada dalan suatu organisasi yang mempunyai peran yang sangat penting.

b. Money

Money merupakan alat bantu berupa alat pembayaran untuk kelancaran operasional baik intern maupun ekstern.

c. Method

Method merupakan suatu cara menggunakan semua sistem yang etektif dan efisien untuk mencapai tujuan yang telah ditetapkan

d. Machine

Manajemen akan berfungsi jika produksi berjalan, maka machine disini adalah merupakan proses produksi suatu produk dari bahan mentah ke bahan jadi

e. Material

Material adalah segala sesuatu yang berhubungan dengan peralatan dan perlengkapan untuk mendukung kegiatan operasional

f. Market

Pangsa pasar yang ada untuk menjual produk yang dihasilkan melalui sistem distribusi yang dipakai.

Dalam suatu organisasi atau perusahaan unsur $6 \quad \mathrm{M}$ selalu berhubungan satu 'dengan yang lainnya sehingga unsur-unsur tersebut tidak bisa terpisahkan.

\section{B. Disiplin}

\section{Pengertian Disiplin Kerja}

Secara etimologis disiplin berasal dari bahasa inggnis "disciple" yang berarti pengikut atau penganut pengajaran, latihan dan sebagainya. Disiplin merupakan suatu keadaan tertentu dimana orang-orang yang tergabung dalam organisasi tunduk pada peraturan-peraturan yang ada dengan rasa senang hati. Sedangkan kerja adalah segala aktivitas manusia yang dilakukan untuk menggapai tujuan yang telah ditetapkannya.

Disiplin adalah prosedur yang mengoreksi atau menghukum awahan karena melanggar peraturan atau prosedur. Disiplin merupakan bentuk pengendalian diri pegawai dan pelaksanaan yang teratur dan menunjukkan tingkat kesungguhan tim kerja di dalam sebuah organsasi. (Sulistiyani, 2009:290)

Menurut Handoko (2013:208), disiplin adalah kegiatan manajemern untuk menjalankan standar-standar organisasional. Hal ini berarti disiplin menjadi acuan bagi organisasi dalam menentukan standar-standar yang dilakukan di organisasi.

\section{Tujuan dan Manfaat Disiplin}

Menurut Simamora dalam Sinambela (2012:243) tujuan utama tindakan pendisiplinan adalah memastikan bahwa perilaku-perilaku pegawai konsisten dengan aturanaturan yang ditetapkan olch organisasi Berbagai aturan yang disusun oleh organisasi adalah tuntunan untuk mencapai tujuan organisasi yang ditetapkan. Pada saat suatu aturan dilanggar, efektivitas organisasi berkurang sampai pada tingkat tertentu, tergantung pada kerasnya pelanggaran.

Tindakan pendisiplinan juga dapat membantu pegawai supaya menjadi lebih produktif, dengan demikian dapat menguntungkannya dalam jangka waktu panjang. 
Tindakan pendisiplinan yang tepat dapat mendorong pegawai untuk meningkatkan kinerja yang pada akhirnya akan menghasilkan pencapaian individu

\section{Pentingnya Disiplin Kerja}

Disiplin kerja adalah kemampuan kerja seseorang untuk secara teratur, tekun, terus-menerus dan bekerja sesuai dengan aturan-aturan yang berlaku dengan tidak melanggor aturan-aturan yang sudah ditetapkan. Menurut Mangkunegara dalam Sinambela (2012:239), terdapat dua jenis bentuk disiplin kerja, yaitu disiplin preventif dan disiplin korektif.

Pendapat lainnya diungkapkan oleh Sutrisno (2013.88) bahwa disiplin kerja sangat diperlukan untuk menunjang kelancaran segala aktifitas organisasi agar tujuan organisasi dapat dicapai secara maksimal Disiplin kerja dapat dilihat sebagai sesuatu yang besar manfaatnya, baik bagi kepentingan organisasi maupun kepentingan pegawai.

\section{METODOLOGI PENELITIAN}

\section{A. Ruang Lingkup Penelitian}

\section{Tempat Penelitian}

Dalam penelitian ini, peneliti mengambil lokasi penelitian padla PT. Handaru Nusantara Gemilang yang beralamat di Villa Pamulang Mas Blok E3 No. 11 Bambu Apus Pamulang Tangerang Selatan.

\section{Waktu Penelitian}

Penelitian dilaksanakan

selama 2 (dua) bulan yaitu dari bulan Maret 2018 sampai dengan bulan April 2018. Penelitian ini dilaksanakan secara bertahap diambil dengan pra riset mulai dari pendahuluan, pengajuan proposal, pengajuan surat ijin, konsultasi dan penyebaran kuisioner dan pengolahan data penyusunan skripsi

\section{Sifat Penelitian}

Sifat penelitian ini adalah deskripsi kuantitatif yaitu penelitian tentang data yang dikumpulkan dan dinyatakan dalam bentuk angka angka, meskipun juga berupa data kualitatif sebagai pendukungnya, seperti katakata atau kalimat yang tersusun dalam angket.

\section{B. Metode Penelitian \\ 1. Populasi}

Menurut Sugiyono (2012:80) mengemukakan defnisii populasi adalah wilayah generalisasi yang terdiri atas objek yang mempunyai kualitas dan karakter tertentu yang ditetapkan oleh peneliti untuk dipelajari dan kemudian ditarik kesimpulan. Populasi dalan penelitian ini adalah seluruh karyawan PT. Handaro Nusantara Gemilang yang berjumlah 60 orang.

\section{Sampel}

Menurut Sugiyono (2012:81) sampel dapat didefinsikan sebagai suatu bagian yang ditarik dari populasi Teknik sampling yang digunakan pada penelitian adalah sampel jenuh adalah teknik penentuan sampel bila semua anggota populasi digunakan sebagai sampel (Sugiyono, 2012:68) Jadi, sampel dalam penelitian ini seluruh karyawan yang berjumlah 60 orang

\section{Metode Pengumpulan Data}

Metode penumpulan data terdiri dari:

\section{Data Primer}

Data primer adalah data yang diperoleh langsung melalui objek penelitian berupa dokumen-dokumen 
penting yang berkaitan den masalah yang diteliti.

\section{Data Sekunder}

Data sekunder adalah data yang diperoleh dari sumber-sumber media dan elektronik (bahan dari objek penelitian). Dalam melakukan penelitian untuk memperoleh data, maka penulis akan menggunakan metode penulisan melalui :

a. Studi Kepustakaan

Dalam penelitian ini penulis memperoleh data dengan menggunakan dan mempelajari literatur atau bahan bacaan seperti buku, jurnal, majalah, dan lain-lain yang berhubungan dengan masalah yang diteliti

b. Studi Lapangan

Penelitian dilakukan untuk mengumpulkan data-data informasi pada objek penelitian dengan teknik sebagai berikut 1) Observasi

Penulis melakukan proses pengamatan data yang terlebih dahulu melakukan pengamatan langsung ke lokasi penelitian. Pengamatan ini merupakan salah satu cara untuk mendapatkan revelan dengan masalah yang diteliti, dalam hal ini dilakukan di PT. Handaru Nusantara Gemilang

2) Angket atau Kuesioner

Angket merupakan teknik pengumpulan data yang dilakukan dengan cara memberi seperangkat pertanyaan atau pernyataan tertulis kepada responden untuk dijawabnya (Sugiyono, 2009:135) Untuk mengukur skala ini digunakan skala likert masing-masing diberi Skor sampai 5 dengan bobot masing masing pertanyaan
a) Jawaban a Sangat Setuju dengan nilai 5
b) Jawaban b Setuju (S) dengan nilai 4

c) Jawaban Ragu-Ragu (R) dengan nilai 3

d) Jawaban d Tidak Setuju (TS) dengan nilai 2 e) Jawaban e Sangat Tidak Setuju (STS) dengan nilai 1

\section{Metode Analisis Data}

Untuk menganalisis hubungan disiplin kerja terhadap prestasi kerja karyawan khususnya di PT. Handaru Nusantara Gemilang, maka data yang diperoleh dari hasil metode kuisioner dianalisis dengan menggunakan metode kuantitaif

\section{Uji Validitas}

Menurut Azwar 2011 173) validitas berasal dari kata validity yang mempunyai arti sejauh mana ketepatan dan kecermatan suatu alat ukur dalam melakukan fungsi ukurannya Atau dengan kata lain mampu tidaknya suatu alat ukur tersebut mencapai tujuan pengukurannya yang dikehendaki dengan tepat. pun umuts mengukur kesahihan angket tepat.

\section{Uji Reliabilitas}

Dalam penelitian ini untuk uji reliabilitas menggunakan sistem internal consistency, menurut Sugiyono (2011:185) sistem internal consistency dilakukan dengan cara mencobakan instrument sekali saja, kemudian data yang diperoleh dianalisis dengan teknik tertentu.

\section{Analisis Korelasi Sederhana}

Menurut Sugiyono (2012:180), fungsi utama dari analisis korelasi adalah untuk menentukan seberapa erat hubungan antara variabel satu dengan lainnya. Analisis korelasi dalam penelitian ini untuk mengetahui seberapa besar hubungan antara variabel $\mathrm{X}$ dan variabel $\mathrm{Y}$. 
Tabel Pedoman untuk Memberikan Interpretasi Koefisien Korelasi

\begin{tabular}{|c|c|}
\hline Interval & Tingkat \\
Koefisien & Hubungan \\
\hline $\mathbf{0 , 0 0 - 0 , 1 9 9}$ & Sangat Rendah \\
$\mathbf{0 , 2 0 - 0 , 3 9 9}$ & Rendah \\
$\mathbf{0 , 4 0 - 0 5 9 9}$ & Sedang \\
$\mathbf{0 , 6 0 - 0 , 7 9 9}$ & Kuat \\
$\mathbf{0 , 8 0 - 1 , 0 0}$ & Sangat Kuat \\
\hline
\end{tabular}

Sumber : Sugiyono (2012:183)

Semakin tinggi koefisien korelasi (rxy) antara variabel bebas (X) dan variabel terikat $(\mathrm{Y})$, maka tingkat hubungan antara kedua variabel tersebut semakin tinggi dan sebaliknya, Koefisien korelasi (rxy) digunakan untuk mengetahui hubungan antara kedua variabel tersebut dengan ketentuan:

a. Apabila nilai rxy>0

Artinya hubungan antara variabel bebas $(\mathrm{X})$ dan variabel terikat (\%) merupakan hubungan positif, sehingga semakin besar nilai variabel bebas (X), maka semakin besar pula nilai variabel terikat (Y) atau sebaliknya semakin kecil nilai yariabel bebas $(\mathrm{X})$, maka semakin kecil pula nilai variabel terikat $(\mathrm{Y})$

b. Apabila $\mathrm{rxy}<0$

Artinya hubungan antara variabel bebas $(\mathrm{X})$ dan variabel terikat (Y) merupakan hubungan negatif, sehingga semakin besar nilai negatif variabel bebas $(\mathrm{X})$, maka semakin besar pula nilai negatif variabel terikat (Y) atau sebaliknya semakin kecil nilai negatif variabel bebas (X), maka semakin kecil pula nilai negatif variabel terikat ()

c. Apabila nilai $\mathrm{rxy}=0$

Artinya tidak terdapat hubungan sama sekali antara variabel bebas (X) dengan variabel terikat (Y) d. Apabila nilai $r x y=1$
Artinya terdapat hubungan positif yang sempurna antara variabel bebas $(\mathrm{X})$ dangan variabel terikat $(\mathrm{Y})$ e. Apabila nilai $r x y=-1$ Artinya terdapat hubungan negatif yang sempurna antara variabel bebas (X) dengan variabel terikat (Y)

\section{Analisis Koefisien Determinasi}

Tujuan analisis koefisien determinasi adalah untuk mengetahui seberapa besar kontribusi variabel bebas terhadap variabel terikat dalam persen ( \% ). Adapun tujuan analisis determinasi dalam penelitian ini adalah untuk mengetahui seberapa besar kontribusi kedisiplinan terhadap prestasi karyawan dalam persen ( \% ). 5. Analisis Regresi Linier Sederhana Analisis regresi linier sederhana adalah pengaruh secara linier antara satu variabel $(\mathrm{x})$ dengan variabel (Y). Analisis ini untuk mengetahui arah pengaruh variabel (X) terhadap variabel (Y) apakah positif atau negatif dan untuk memprediksi nilai dari variabel (Y) apahla nilai variabel $(\mathrm{X})$ mengalami kenaikan atau penurunan. Data yang digunakan biasanya berskala interval atau rasio.

\section{Analisis Uji Hipotesis}

Untuk memperkuat hasil perhitungan yang diperoleh untuk mengetahui tingkat kebenaran pengaruh antara dua variabel yaitu variabel $\mathrm{X}$ dan $\mathrm{Y}$, maka penulis akan melakukan uji hipotesis dengan langkah-langkah sebagai berikut :

a. Merumuskan hipotesis

Adapun hipotesis yang diajukan dalam penelitian ini adalah sebagai berikut:

H0: $\beta=0$ tidak terdapat pengaruh kedisiplinan terhadap prestasi kerja karyawan PT. Handaru Nusantara Gemilang 
$\mathrm{H} 1: \beta \quad \# 0 \quad$ terdapat pengaruh kedisiplinan terhadap prestasi kerja karyawan PT. Handaru Nusantara Gemilang

\section{PEMBAHASAN PENELITIAN}

DAN

\section{A. Gambaran Umum Objek Penelitian}

\section{Sejarah Singkat Perusahan PT. Handaru Nusantara Gemilang}

Membuat wangi nama bangsa dan negara merupakan kewajiban dari masyarakat, terutama para pemuda Indonesia. Memiliki semangat nasional untuk selalu ingin membanggakan negara sendiri adalah hal yang paling dibutuhkan dalam membangun Indonesia menjadi negara yang lebih baik lagi.

Hal lain yang bisa dilakukan adalah membuat usaha atau bisnis yang menggambarkan Indonesia dan mampu membawanya sampai ke luar negeri. Memakai budaya Indonesia sebagai daya tarik utama bisnis seseorang, mencerminkan seseorang yang bangga terhadap tanah air sendiri adalah bentuk dari perjuangan. Contoh pilihan bisnis yang dapat menggambarkan kekayaan budaya Indonesia adalah bisnis kuliner.

Dengan mengangkat brand Dapoer Intan yang bergerak dalam bidang kuliner dibawah naungan PT. Handaru Nusantara Gemilang, yang termasuk dalam bisnis UMKM termotivasi pula dari adanya pengaruh MEA. Mengangkat para pekerja agar terhindar dari adanya pengangguran. Pepes ikan saat ini telah menjadi salah satu kuliner favorit masyarakat Indonesia. Pepes yang awalnya merupakan kuliner tradisional khas Jawa semakin banyak digemari karena rasanya yang khas, sangat nikmat dijadikan teman makan nasi yang hangat.

Namun sekarang kita dapat menikmati pepes ikan. sepenti pepes bandeng dengan duri lunak tanpa direpotkan dengan daun pembungkus yang merepotkan dengan hadirnya "Pepes Bandeng Duri Lunak".

\section{Visi dan Misi Perusahaan}

Pengertian visi adalah suatu pandangan jauh tentang perusahaan tujuan perusahaan dan apa yang harus dilakukan untuk mencapai tujuan tersebut. Misi adalah pernyataan tentang apa yang harus dikerjakan oleh lembaga dalam usahanya mewujudkan visi. Berikut adalab visi dan misi perusahaan PT. Handaru Nusantara Gemilang:

a. Visi

Menjadikan Pepes Bandeng yang aman, halal, bergizi dan berkualitas sehingga menjadi makanan favorit pilihan keluarga Indonesia yang akan menjadi oleh-oleh khas Tangerang Selatan yang bisa mendunia.

b. Misi

1) Menerapkan proses produksi sesuai dengan CPPOB cara pengolahan pangan dan obat yang baik)

2) lkut menggalakan gemar ikan dimasyarakat indonesia, agar generasi kita sehat dan cerdas 3) Pemberdayaan masyarakat sekitar dengan mendirikan "KAMPUNG PEPES BANDENG

\section{Struktur Organisasi}

Dalam setiap organisasi pasti memerlukan struktur organisasi agar dapat mengorganisasikan semua kegiatan secara efisien dan efektif, yang dapat memberikan gambaran sistematis tentang hubungan kerja 
sama antar kelompok orang-orang yang terlibat didalamnya untuk mencapai suatu tujuan.

\section{Hasil Penelitian dan Pembahasan}

1. Karakteristik Responden

a. Berdasarkan Jenis Kelamin Responden

Dalam penelitian ini, penulis mengambil sampel data responden adalah seluruh karyawan pada PT. Handaru Nusantara Gemilang yang berjumlah 60 orang.

Data Responden Berdasarkan Jenis Kelamin

\begin{tabular}{|c|c|c|c|}
\hline $\begin{array}{c}\text { No } \\
\text { • }\end{array}$ & $\begin{array}{c}\text { Jenis } \\
\text { Kelamin }\end{array}$ & $\begin{array}{c}\text { Jumla } \\
\text { h } \\
(\text { Oran } \\
\text { g) }\end{array}$ & $\begin{array}{c}\text { Presenta } \\
\text { se }(\%)\end{array}$ \\
\hline 1. & Laki-laki & 11 & $18 \%$ \\
\hline 2. & $\begin{array}{c}\text { Perempu } \\
\text { an }\end{array}$ & 49 & $82 \%$ \\
\hline \multicolumn{2}{|c|}{ Jumlah } & 60 & $100 \%$ \\
\hline
\end{tabular}

Sumber : Data olahan kuesioner 2018

Berdasarkan data diatas dapat dilihat bahwa presentase jenis kelamin pekerja yang populasinya paling banyak adalah pekerja yang memiliki jenis kelamin perempuan yaitu sebanyak 49 orang atau $82 \%$, sedangkan presentase jenis kelamin pekerja yang populasinya paling sedikit adalah pekerja yang memiliki jenis kelamin laki-laki, yaitu sebanyak 11 orang atau $18 \%$.

b. Berdasarkan Status

Berikut data responden sesuai kuesioner yang disebarkan berdasarkan status terakhir karyawan PT Handaru Nusantaca Gemilang dapat dilihat scbagai berikut:
Data Responden Berdasarkan

Status

\begin{tabular}{|c|l|c|c|}
\hline No. & Status & $\begin{array}{c}\text { Jumlah } \\
(\text { Orang) }\end{array}$ & $\begin{array}{c}\text { Presentase } \\
(\boldsymbol{\%})\end{array}$ \\
\hline 1. & $\begin{array}{c}\text { Belum } \\
\text { Menikah }\end{array}$ & 35 & $58 \%$ \\
\hline 2. & Menikah & 25 & $42 \%$ \\
\hline \multicolumn{2}{|c|}{ Jumlah } & $\mathbf{6 0}$ & $\mathbf{1 0 0 \%}$ \\
\hline
\end{tabular}

Sumber : Data olahan kuesioner 2018

Berdasarkan data diatas dapat dilihat bahwa presentase status yang populasinya paling banyak adalah pekerja yang berstatus belum menikah yaitu sebanyak 35 orang atau $58 \%$, sedangkan presentase status pekerja yang populasinya paling sedikit adalah pekerja yang memiliki status menikah yaitu sebanyak 25 orang atau $42 \%$.

c. Berdasarkan Usia Responden Data responden sesuai hasil kuesioner yang telah disebarkan berdasarkan usia karyawan pada PT. Handaru Nusantara Gemilang adalah sebagai berikut :

Data Responden Menurut Usia

\begin{tabular}{|c|c|c|c|}
\hline No. & Usia & $\begin{array}{c}\text { Jumlah } \\
\text { (Orang) }\end{array}$ & $\begin{array}{c}\text { Presentase } \\
(\mathbf{\%})\end{array}$ \\
\hline 1. & $\begin{array}{c}<20 \\
\text { thn }\end{array}$ & 18 & $30 \%$ \\
\hline 2. & $\begin{array}{c}21- \\
30 \\
\text { thn }\end{array}$ & 20 & $33 \%$ \\
\hline 3. & $\begin{array}{c}31- \\
40 \\
\text { thn }\end{array}$ & 15 & $25 \%$ \\
\hline 4. & $\begin{array}{c}>40 \\
\text { thn }\end{array}$ & 7 & $12 \%$ \\
\hline \multicolumn{2}{|c|}{ Jumlah } & $\mathbf{6 0}$ & $\mathbf{1 0 0 \%}$ \\
\hline
\end{tabular}

Sumber : Data olahan kuesioner 2018

Berdasarkan data diatas bisa disimpulkan bahwa responden atau karyawan yang terlihat dalam penelitian menurut usia 20 tahun 
sebanyak 18 orang atau 30\%, 21-30 tahun sebanyak 20 orang atau 33\%, 31-40 tahun sebanyak 15 orang atau $25 \%,>40$ tahun sebanyak 7 orang atau $12 \%$.

d. Berdasarkan Pendidikan Terakhir Responden

Untuk lebih jelasnya, data responden sesuai kuesioner yang disebarkan berdasarkan tingkat pendidikan terakhir karyawan pada PT. Handaru Nusantara Gemilang dapat dilihat sebagai berikut :

\begin{tabular}{|c|c|c|c|}
\hline \multicolumn{4}{|c|}{$\begin{array}{l}\text { Data Responden Menurut } \\
\text { Pendidikan Terakhir }\end{array}$} \\
\hline $\begin{array}{l}\mathbf{N} \\
\mathbf{0}\end{array}$ & $\begin{array}{l}\text { Pendidik } \\
\text { an }\end{array}$ & $\begin{array}{c}\text { Jumla } \\
\text { h } \\
\text { (Oran } \\
\text { g) }\end{array}$ & $\begin{array}{l}\text { Present } \\
\text { ase }(\%)\end{array}$ \\
\hline 1. & $\begin{array}{c}\text { SLTA } \\
\text { atau } \\
\text { Sederajat }\end{array}$ & 44 & $74 \%$ \\
\hline 2. & D3 & 8 & $13 \%$ \\
\hline 3. & S1 & 5 & $8 \%$ \\
\hline 4. & S2 & 3 & $5 \%$ \\
\hline & Jumlah & 60 & $100 \%$ \\
\hline
\end{tabular}

Sumber : Data olahan kuesioner 2018

Berdasarkan data diatas dapat disimpulkan bahwa karyawan PT Handaru Nusantara Gemilang yang menjadi responden bahwa rata- rata pendidikan terakhir adalah SLTA atau sederajat sebanyak 44 orang atau $74 \%$ , D3 sebanyak 8 orang atau $13 \%, \mathrm{~S} 1$ sebanyak 5 orang atau $8 \%$ dan S2 sebanyak 3 orang atau $5 \%$.

\section{Hasil Penelitian}

Penelitian ini dilakukan dengan cara pengamatan maupun penyebaran kuesioner kepada 60 responden dari karyawan pada PT. Handaru Nusantara sebagai sampel dengan skor yang diberikan sebagai berikut:
Data Skor Tiap Butir Jawaban Variabel

\begin{tabular}{|c|c|}
\hline Pilihan Jawaban & $\begin{array}{c}\text { Peringkat } \\
\text { Nilai (Skor) }\end{array}$ \\
\hline $\begin{array}{c}\text { SS (Sangat } \\
\text { Setuju) }\end{array}$ & 5 \\
\hline S (Setuju) & 4 \\
\hline R (Ragu-ragu) & 3 \\
\hline $\begin{array}{c}\text { TS (Tidak } \\
\text { Setuju) }\end{array}$ & 2 \\
\hline $\begin{array}{c}\text { STS (Sangat } \\
\text { Tidak Setuju) }\end{array}$ & 1 \\
\hline
\end{tabular}

Sumber : Data olahan kuesioner 2018

\section{KESIMPULAN DAN SARAN}

\section{A. Kesimpulan}

Berdasarkan hasil penelitian dan pembahasan yang telah diuraikan di atas, maka penulis dapat menarik suatu kesimpulan sebagai berikut

1. Berdasarkan data responden dari hasil kuesioner 10 pernyataan pada variabel Kedisiplinan (X) menunjukan bahwa mayoritas responden dalam penelitian ini memberikan jawaban " Sangat Setuju " sebanyak 54\% 323 ) dan " Setuju " sebanyak 41\% ( 245 ). Artinya, Kedisiplinan pada PT Handaru Nusantara Gemilang dengan Brand Dapoer Intan yang bergerak dalam pembuatan pepes bandeng sudah berjalan dengan baik.

2. Berdasarkan data responden dari hasil kuesioner 10 pernyataan pada variabel Prestasi Kerja Karyawan (Y) menunjukan bahwa mayoritas responden dalam penelitian ini memberikan jawaban "Sangat Setuju" sebanyak 48\% ( 290 ) dan "Setuju " sebanyak 46\% ( 278 ). Artinya Prestasi Kerja Karyawan pada PT. Handaru Nusantara Gemilang dengan Brand Dapoer Intan yang bergerak dalam pembuatan pepes bandeng sudah berjalan dengan baik. 
3. Berdasarkan analisis diperoleh nilai korelasi (r) sebesar 0,66063, hal ini memberikan indikasi bahwa Kedisiplinan (X) memiliki hubungan yang kuat dalam upaya meningkatkan prestasi kerja karyawan (Y) pada PT. Handaru Nusantara Gemilang dengan Brand Dapoer Intan yang bergerak dalam pembuatan pepes bandeng. Sementara hasil persamaan regresi sederhana adalah $\hat{\mathbf{Y}}=\mathbf{1 4 , 9 3}$ 0,6540X. Nilai koefisien regresi variabel Kedisiplinan (X) terhadap variabel Prestasi Kerja Karyawan (Y) adalah sebesar 0,6540. Hal ini berarti jika disiplin naik satu-satuan, maka akan meningkatkan prestasi kerja karyawan sebesar 0,6540. Nilai Koefisien Determinasi ( $\mathrm{KD})=$ 43,64\%, menunjukan bahwa kontribusi Kedisiplinan terhadap Prestasi Kerja Karyawan pada PT. Handaru Nusantara Gemilang dengan Brand Dapoer Intan yang bergerak dalam pembuatan pepes bandeng sebesar 43,64\%, sedangkan selebihnya yaitu $56,35 \%$ dipengaruhi oleh faktor lain yang tidak diteliti oleh penulis. Uji signifikan diperoleh nilai thitung sebesar 6,7020 > ttabet sebesar 2,002, maka menunjukan hasil yang signifikan antara kedisiplinan terhadap prestasi kerja karyawan.

\section{B. Saran}

Berdasarkan hasil pembahasan dan kesimpulan di atas dapat Penulis sampaikan saran-saran sebagai berikut:

\section{Ketaatan pada Peraturan Kerja} merupakan indikator yang mendapatkan respon jawaban "Raguragu" yang paling banyak dalam hasil kuesioner variabel Kedisplinan (X). Oleh karena itu, Penulis menyarankan agar setiap peraturan kerja haruslah ditaati agar setiap karyawan melailaikan prosedur kerja dan akan selalu mengikuti pedoman ditetapkan oleh perusahaan. Dan perlu adanya ketegasan dari atasan untuk memberikan teguran bahkan sanksi apabila karyawan tidak menyelesaikan tugas dengan baik sehingga karyawan akan menjadi lebih baik dalam mengoptimalkan prestasi kerja karyawan pada masa yang akan dating.

2. Penguasaan menjadi permasalahan pada PT. Handaru Nusantara Gemilang dengan Brand Dapoer Intan yang hergerak dalam pembuatan pepes bandeng, hal ini dibuktikan dari tanggapan responden pada variabel prestasi kerja karyawan menyatakan "Ragu-ragu" paling banyak. Penulis menyarankan agar pengusaan setiap karyawan harus terus diasah dan dikembangkan melalui program training ataupun bimbingan agar dapat menghasilkan sesuatu yang lebih bermanfaat dan bernilai tambah bagi dirinya maupun bagi orang lain.

\section{DAFTAR PUSTAKA}

Azwar. "Manajemen Sumber Daya Manusia". Bandung: Sulita. 2011.

Follet, Mary Parker. "Manajemen Personatia dan Sumber Daya Mamusia". Jakarta Raja Grafindo Persada. 2013.

George. R.Terry dalam Rivai. "Perencanaan Sumber Daya Mamsia". Jakarta: PT. Raja Grafindo Persada. 2012.

Heidjrachman dan Husnan. "Manajemen Sumber Daya Manusia". Jakarta: Bumi Aksara. 2012. 
James A.F Stoner dalam Rivai. Robbins dan Couher. "Managemen "Perencanaan Sumber Daya Kinerja". Jakarta: PT. Raja Manusia". Jakarta: PT Raja Grafindo Persada. 2009.

Grafindo Persada. 2011.

Latainer. "Manajemen Sumber Daya Manusia". Jakarta: Kencana Prenada Media Group. 2013.

Mangkunegara, A.A Prabu. "Manajemen Sumber Daya Manusia". Bandung: Remaja Rosdakarya. 2009.

Subekti dkk. "Evaluasi Kinerja Karyawan”. Yogyakarta: Aswaja Pressindo. 2012.

Sugiyono. "Metodologi Penelitian Kualitaif, Kuantitatif dan $R \& D$ ", Bandung: CV Alfabeta. 2009.

Sulistiani. "Statistika Terapan Untuk Perguruan Tinggi". Jakarta: Prenada Media. 2009.

Sumber Daya Manusia". Bogor: InMedia 2014.

Nitisemito. "Evaluasi Kinerja Sutrisno. Edy. "Manajemen Sumber SDAM". Jakarta: Prenada Media. 2010.

Daya Manusia". Jakarta: Kencana Prenada Media Group. 2009. 